\title{
LETTERS
}

\section{Responsible use of rifampin in Canada is threatened by irresponsible shortages}

We agree wholeheartedly with Drs. Batt and Khan's description of rifampin as "unequivocally the most important drug in the global fight against [tuberculosis] TB." ${ }^{1}$ However, using a drug effectively requires that it be available in the first place. Disturbingly, rifampin is becoming increasingly difficult to acquire in Canada; both companies that sell it (Sanofi and Bausch Health) are facing long-term shortages and the imminent potential for indefinite total stockouts. $^{2}$

Rifampin is the cornerstone of care for active TB disease, forming part of all firstline treatment regimens, ${ }^{3}$ as well as a valuable treatment for latent TB infection. These shortages of rifampin pose a real threat to TB care $^{4}$ in Canada, including the prevention and treatment of active TB in the Indigenous communities most affected by the disease. ${ }^{5}$

The Government of Canada has consistently failed to offer adequate longterm solutions and short-term fixes for frequent drug shortages. ${ }^{6}$ For past shortages of other basic TB drugs like ethambutol, existing mechanisms like Health Canada's Special Access Programme have not proven to be effective stopgap measures. Although the new Access to Drugs in Exceptional Circumstances mechanism, which allows temporary access to drugs without market authorization in Canada in response to an urgent public health need, has proven helpful in accessing rifapentine, ${ }^{7}$ another drug for latent TB infection, its usefulness in addressing shortages of drugs that are already authorized in Canada remains unclear.

Canada has already recognized the vital importance of sustainable access to crucial TB drugs in lower-income countries, becoming the largest single-country donor for first-line drugs like rifampin to the Global Drug Facility, a global bulk procurer of TB medicines. ${ }^{8}$ Given the looming threat to both public health and patient care, we call on the Canadian government to devote similar effort and resources to ensuring continuous access at home, both through stronger regulatory measures to prevent domestic drug shortages and the authorization of alternative sources for TB drugs such as the Global Drug Facility.

\section{Adam R. Houston JD MA}

Faculty of Law, University of Ottawa, Ottawa, Ont.

\section{Ryan Cooper MD MPH}

Associate teaching professor, Division of Infectious Disease, Faculty of Medicine, University of Alberta, Edmonton, Alta.

\section{Faiz Ahmad Khan MD MPH}

Associate director, McGill International TB Centre, Research Institute of the McGill University Health Centre; TB clinic director, Montreal Chest Institute, Montréal, Que.
Cite as: CMAJ 2019 October 15;191: E1139. doi: $10.1503 / \mathrm{cmaj} .73160$

\section{References}

1. Batt J, Khan K. Responsible use of rifampin for the treatment of latent tuberculosis infection. CMAJ 2019;191:E678-9.

2. Drug Shortages Homepage. Ottawa: Health Canada. Available: www.drugshortagescanada.ca/ (accessed 2019 July 6).

3. Nahid P, Dorman SE, Alipanah N, et al. Official American Thoracic Society/Centers for Disease Control and Prevention/Infectious Diseases Society of America clinical practice guidelines: treatment of drug-susceptible tuberculosis. Clin Infect Dis 2016;63:e147-95.

4. Scott JC, Shah N, Porco T, et al. Cost resulting from anti-tuberculosis drug shortages in the united states: a hypothetical cohort study. PLOS One 2015;10:e0134597.

5. Tam T. The time is now: CPHO spotlight on eliminating tuberculosis in Canada [monograph]. Ottawa: Public Health Agency of Canada; 2018. Available: publications.gc.ca/pub ?id=9.856223\&sl=0 (accessed 2019 July 6).

6. Donelle J, Duffin J, Pipitone J, et al. Assessing Canada's Drug Shortage Problem. no 515 of C.D. Howe Institute Commentary series. Toronto: C.D. Howe Institute; 2018. Available: www. cdhowe.org/sites/default/files/attachments/ research_papers/mixed/Commentary_515.pdf (accessed 2019 July 6).

7. List of drugs for an urgent public health need. Ottawa: Health Canada; [modified 2010 Sept. 9]. Available: www.canada.ca/en/health-canada/ services/drugs-health-products/access-drugs -exceptional-circumstances/list-drugs-urgent -public-health-need.html (accessed 2019 July 6).

8. Project profile - global drug facility: provision of anti-tuberculosis drugs. Ottawa: Government of Canada. Available: https://w05.international. gc.ca/projectbrowser-banqueprojets/project -projet/details/m011474003 (accessed 2019 July 6).

Competing interests: None declared. 